\title{
Kemik Mineral Dansitesi ile Biyokimyasal Parametreler Arasındaki İlişki
}

The Relationship Between Bone Mineral Densityand Some Blood Parameters

${ }^{1}$ Yildırım Beyazıt Aile Sağlığı Merkezi, Aile Hekimliği Uzmanı, Kütahya, Türkiye

${ }^{2}$ Cumhuriyet Aile Sağlığı Merkezi, Aile Hekimliği Uzmanı, Kütahya, Türkiye
Correspondence: Adem DURMAZ

Yıldırım Beyazıt Aile Sağlığı Merkezi, Aile Hekimliği Uzmanı, Kütahya, Türkiye e-mail: addurmaz@gmail.com
${ }^{1}$ Adem Durmaz, ${ }^{2}$ Çağla Özdemir

Çalışmamızda, kemik mineral dansitesi ile bazı kan parametreleri arasındaki ilişkinin incelenmesi amaçlanmıştır. Kesitsel retrospektif dizaynda olan bu çalışmaya 2018-2020 tarihleri arasında Yoncalı Fizik Tedavi ve Rehabilitasyon Hastanesi'ne başvuran hastalar dahil edilmiştir. Kronik hastalık kaydı olmayan, mevcut kan tetkikleri ve kan mineral dansitometri sonucu olan 282 kişi çalışmaya alındı. Hastaların \%56,4'ünde (n:159) osteoporoz, \%27,6'sında (n:78) osteopeni mevcuttu ve geri kalan \%16'sı (n:45) sağlıklı bireylerden oluşmaktaydı. Yaş ortalaması incelendiğinde osteoporotik grubun 66 yıl, osteopenik grubun 61 yıl ve kontrol grubunun 59 yll idi. Mean platelet volume (MPV) ve MPV/Plt değerleri arasında her üç grupta da anlamlı bir fark saptanmad $(\mathrm{p}>0,05)$. Ayrıca üre, kreatin, Alanin transaminazın (ALT) osteoporoz $(\mathrm{p}<0,05)$ ile glukoz düzeylerinin osteopenik grup ile ilişkili olduğu saptandı. Aspartat transaminaz (AST), magnezyum (Mg), kalsiyum (Ca), fosfor (P), albümin, CRP, sedimentasyon, beyaz kan hücreleri (WBC), trombosit (Plt) sayılarının her üç grupta da anlamlı bir fark olmadığı saptandı (p>0,05). Ürik asit ve Trombosit Dağılım Genişliğinin (PDW) de kemik kitlesi ile ilişkili olduğu gözlendi. Kemik dansitesi yaşla ters orantılı olarak azalmaktaydı. Osteoporozun kadınlarda osteopeni ve kontrol grubuna kıyasla daha sık olduğu saptandı. D vitamininin de kemik kitlesiyle ilişkili olduğu saptandı. Kemik kitlesi azaldıkça Nötrofil Lenfosit Oranı (NLO) artmaktadır. Ancak MPV değerleri ile kemik kitlesi arasında herhangi bir ilişki saptanmadı.

Anahtar Kelimeler: Kemik mineral dansitesi; osteoporoz; D vitamini; Mean Platelet Volume; Nötrofil/Lenfosit oranı

\section{Abstract}

The aim of our study is to investigate the relationship between bone mineral density and blood cell sand vitamin D levels. Hospital between 2018-2020 were included in this cross-sectional retrospective study. 282 people who did not have a chronic disease record and who had blood tests and blood mineral densitometry results were included in the study. $\quad 56.4 \%$ (n: 159) of the patients had osteoporosis, $27.6 \%$ (n: 78) had osteopenia, and the remaining 16\% (n: 45) consisted of healthy individuals. When the mean age was examined, it was 66 years in the osteoporotic group, 61 years in the osteopenic group and 59 years in the control group. There was no significant difference between the mean platelet volume (MPV) and MPV / Plt values in all three groups (p> $0.05)$. In addition, it was found that urea, creatine, Alanine transaminase (ALT), osteoporosis $(\mathrm{p}<0.05)$ and glucose levels were associated with the osteopenic group. Aspartate transaminase (AST), magnesium (Mg), calcium (Ca), phosphorus (P), albumin, CRP, sedimentation, white blood cells (WBC), platelet (Plt) counts were not found to be significantly different in all three groups $(\mathrm{p}>0.05)$. It was observed that uric acid and Platelet Distribution Width (PDW) values were also associated with bone mass. Bone density decreased inversely with age. It was found that osteoporosis was more common in women (compared to osteopenia and control group). Vitamin D was also found to be associated with bone mass. As the bone mass decreases, the Neutrophil Lymphocyte Ratio (NLR) increases. However, no correlation was found between MPV values and bone mass.

Keywords: Bone mineral density; osteoporosis; Vitamin D; Mean platelet volume; Neutrophil/Lymphocyte ratio 


\section{Giriş}

Osteoporoz, kemik kütlesinin azalmas1, trabeküler mikro mimarinin bozulması ve kırılganlığın artması ile karakterizedir. Başka bir ifadeyle, kemik dokuda yıllar içerisinde gelişen kusurlu sentez, normal günlük aktivitelerden kaynaklanan mikro hasarların kusurlu onarımı ve uygunsuz aşırı kemik oluşumuyla da ilişkilidir $(1,2)$. Erişkinler, 1825 yaşları arasında en yüksek kemik kütlesine sahiptir. $\mathrm{Bu}$ tepe kemik kütlesinin oluşmasında başta genetik olmak üzere, beslenme, endokrin durum, fiziksel aktivite ve büyüme sırasında sağlanan destekleyici faktörler rol oynamaktadır (3). İnsanlarda beklenen yaşam süresinin artması nedeniyle osteoporoz, başta yaşlılar olmak üzere, tüm etnik kökenli insanların, kadın ve erkek herkesin bir halk sağlığ sorunu haline gelmiştir. Özellikle de kalça, omurga ve bilek başta olmak üzere tüm kemiklerimizde kırıklara karşı artan bir yatkınlığa sebep olmaktadır. Gelişebilecek kalça kırıkları hastaneye yatış gerektirdiğinden dolayı oldukça maliyetli ve kötü prognostik bir komplikasyondur. Hatta olguların \%20'sinde ölümcül olduğu bilinmektedir. Kalan \%50'sinde kalıc sakatlıklar birakabilirken sadece \%30'u tamamen iyileşebilir. 1990 yılında dünya çapında 1,7 milyon kalça kırığı meydana gelmiştir; bu rakamın 2050 yılına kadar 6 milyona çıkması beklenmektedir (4).

Bilindiği gibi hematopoetik ve mezenkimal kök hücreleri, kemik iliğinde bulunur ve birbiriyle de yakından ilişkilidir. Son araştırmalarda, başlangıçta izole olarak incelenen bu iki sistemin aslında işlevsel olarak bağlantılı olduğunu göstermiştir. Yapılan çok sayıdaki çalışmada, megakaryositlerin (MK) osteoblast (OB) proliferasyonunu ve gelişimini uyardığını ve osteoklast (OC) gelişimini engellediğini gösteren in vitro ve in vivo kanitlar bulunmuştur. MK'ler, trombosit progenitör hücreleridir. Trombosit fonksiyonunu değerlendirmek için MPV ve PDW yaygın olarak kullanılmaktadır $(5,6)$.

Kemik sağlığımızın devamı ve hatta kaybının önlenmesinde D vitamininin rolü şüphesiz önemlidir (7). D vitamini eksikliği, Ca'un emiliminde azalmaya, kemik mineralizasyonunda yetersizliğe, kas gücünde zayıflamaya ve denge bozukluğu riskinde artmaya sebep olmaktadır. Vitamin D'nin ana biyolojik görevi, temel hücresel işlevlerin sürdürülmesi için serum $\mathrm{Ca}$ ve $\mathrm{P}$ düzeylerinin normal sinırlarda tutulmasi ve iskelet mineralleşmesinin uyarılmasıdır. Ayrıca kemikteki kök hücrelerinin, OC'lere mobilizasyonunu artırarak (bilindiği gibi ihtiyaç halinde bu hücreler $\mathrm{Ca}$ depolarını harekete geçirirler) kan Ca'unu normal aralıkta tutar (8).

Osteoporoz ile D vitamini, kan Ca-P düzeyleri arasında ilişki olduğu bilinmektedir. $\mathrm{Bu}$ çalışmada, kemik mineral dansitesi ile bazı kan parametreleri arasındaki ilişkinin incelenmesi, amaçlanmıştır

\section{Gereç ve Yöntemler}

Çalışma için Kütahya İl Sağlık Müdürlüğü ve Kütahya Sağlık Bilimleri Üniversitesi'nden etik kurul onayı alınmıştır (etik kurul kararı tarih-no:14.07.2020 ve 2020/11-08). Çalışmaya Fizik Tedavi ve Rehabilitasyon hastanesinde 2018-2020 tarihleri arasinda Fizik Tedavisi polikliniğe; kemiklerinde ağr1, kaslarında güçsüzlük, yakın zamanda geçirilmiş kemik kırıkları gibi kemik kitlesinde azalmasını düşündüren şikayetlerle başvuran 282 hasta dahil edildi. Bu hastaların içinde KMD değeri normal olan ve son 6 ay içinde kemik kitlesini etkileyebilecek (kortikosteroid, D vitamini, kemoterapi, radyoterapisi gibi) tedavi almadığını bildirenler kontrol grubu olarak belirlendi. $\mathrm{Bu}$ hastaların Kemik Mineral Dansitometri (KMD) değerleri, D vitamini, hemogram, biyokimya, kalsiyum (Ca), fosfor (P), magnezyum (Mg), C-reaktif proteinleri (CRP) ve sedimantasyon değerleri retrospektif olarak incelendi. KMD değerleri Dünya Sağlık Örgütünün (WHO-DSÖ) belirlediği T skoruna göre sinıflandırıldı. Hastalar KMD değerlerine göre normal, osteopenik ve osteoporotik diye gruplara ayrıldı (9).

Kemik Mineral dansitesini ölçmek için, günümüzde altın standart tanı yöntemi olarak kullanılan (10) DEXA (Dual Energy X-Ray Absorbtiometry) cihaz1 kullanıldi. Ayrica hemogram Horiba ABX Pentra DF 120 cihazı 
ve biyokimya değerleri Becman Coulter AU 5800 cihazında, D vitamini DXI-600 Beckman Coulter immunassay analyzer (Beckman Coulter, Inc., CA, USA) cihazları kullanılarak incelendi.

\section{İstatistiksel analiz}

İstatistiksel analizler SPSS versiyon 21.0 (IBM ${ }^{2}$, Chicago, ABD) paket programı kullanılarak yapıldı. Değişkenlerin normal dağılımına uygunluğu görsel (histogram ve olas1lık grafikleri) ve analitik yöntemler (Shapiro-Wilk testi) kullanılarak incelendi. Tanımlayıcı istatistikler normal dağılan sayısal verilerde ortalama ve standart sapma, nominal verilerde sayı ve yüzde şeklinde ifade edildi. Normal dağılan sayısal değişkenler iki grup arasında "Bağımsız Gruplarda T testi", üç grup arasında "One way ANOVA testi" ile karşılaştırıldı. Normal dağılım göstermeyen sayısal değişkenler iki grup arasında "Mann Whitney U" testi, üç grup arasında "Kruskal Wallis testi" kullanılarak karşılaştırıldı. Nominal veriler iki grup arasında "Ki-kare" testi kullanılarak değerlendirildi. Çalışmadaki istatistiksel analizlerde $\mathrm{p}$ değeri 0,05 'in altındaki karşılaştırmalar istatistiksel olarak anlamlı kabul edilmiştir.

\section{Bulgular}

\section{Sosyodemografik ve klinik özellikler}

Çalışma 282 hasta ile gerçekleştirildi. 159 hastanın osteoporozu, 78 hastanın osteopenisi mevcuttu. 45 hastanın ise herhangi bir ek hastalığ1 yoktu. Hastaların ortalama yaş1 osteoporoz grubunda 66 (23-93) y1l, osteopeni grubunda 61 (29-78) y1l, kontrol grubunda 59 (43-75) yıld1. Osteoporoz ile osteopeni ve kontrol grubu arasında yaş açısından anlamlı fark mevcuttu $(p<0,001)$; ancak osteopeni ile kontrol grubu arasında yaş açısından anlamlı farklilik yoktu $(p=0,323)$. Osteoporoz ile osteopeni grubu arasında kreatin, ürik asit, ALT, D vitamini ve PDW açısından anlamlı farkl111k mevcuttu $(p<0,05)$. Osteoporoz ile kontrol grubu arasinda cinsiyet, üre, kreatin, ALT, D vitamini ve NLO açısından anlamlı ilişki saptand $1(p<0,05)$. Osteopeni ile kontrol grubu arasında glukoz ve NLO açısından anlaml1 fark saptand $1 \quad(\mathrm{p}<0,05)$. Gruplar arasındaki diğer karşılaştırmalarda laboratuar parametreleri açısından anlamlı farklılık izlenmedi $(p>0,05)$.

Kemik mineral yoğunluğuna göre yapılan sinıflamaya göre hastaların sosyodemografik özellikleri ve laboratuar parametreleri tablo 1 'de özetlendi.

KMD femur total skoru ile nötrofil/lenfosit oranı arasında anlamlı bir korelasyon mevcuttu $(p<0,05)$. Ancak KMD femur ve lomber skorları ile diğer laboratuar parametreleri arasında ise anlamlı bir ilişki saptanmadı $(\mathrm{p}>0,05)$. KMD skorlar1 ile kan laboratuvar parametreleri arasındaki ilişki tablo 2'de gösterildi.

Tablo 1. KMD skoru sınıflamasına göre sosyodemografik özellikler ve laboratuar parametreleri

\begin{tabular}{|c|c|c|c|c|c|c|c|}
\hline & & $\begin{array}{c}\text { Osteoporoz } \\
\text { grubu } \\
(\mathbf{N}=159)\end{array}$ & $\begin{array}{c}\text { Osteopeni } \\
\text { grubu } \\
(\mathrm{N}=78)\end{array}$ & $\begin{array}{c}\text { Kontrol } \\
\text { grubu }(\mathrm{N}=45)\end{array}$ & $\begin{array}{c}\text { A } \\
\text { grubu } \\
\text { p } \\
\text { değeri }\end{array}$ & $\begin{array}{c}\text { B } \\
\text { grubu } \\
\mathbf{p} \\
\text { değeri }\end{array}$ & $\begin{array}{c}\text { C } \\
\text { grubu } \\
\underset{p}{\text { değeri }}\end{array}$ \\
\hline Yaş* & $\begin{array}{c}\text { Med } \\
(\min -\max )\end{array}$ & $66(23-93)$ & $61(29-78)$ & $59(43-75)$ & $<0,001$ & $<0,001$ & 0,323 \\
\hline $\operatorname{Kadın}(+)^{* *}$ & $N(\%)$ & $139(87,4)$ & $70(89,7)$ & $44(97,8)$ & 0,603 & 0,044 & 0,099 \\
\hline Glukoz* & $\begin{array}{c}\text { Med } \\
(\min -\max )\end{array}$ & $96(9,3-216)$ & 99 (60-199) & $91(7-160)$ & 0,204 & 0,182 & 0,029 \\
\hline Üre* & $\begin{array}{c}\text { Med } \\
\text { (min-max) }\end{array}$ & $35(0-96)$ & $31(17-69)$ & $32(20-53)$ & 0,025 & 0,033 & 0,875 \\
\hline Kreatin* & $\begin{array}{c}\text { Med } \\
(\min -\max )\end{array}$ & $0,9(0,4-4,6)$ & $0,8(0,6-1,2)$ & $0,8(0,5-1,6)$ & $<0,001$ & 0,010 & 0,928 \\
\hline Ürik asit* & $\begin{array}{c}\text { Med } \\
(\min -\max )\end{array}$ & $5,3(0-13,1)$ & $4,5(2,5-8,3)$ & $5,2(2,5-8,6)$ & 0,004 & 0,426 & 0,122 \\
\hline ALT (IU/L)* & $\begin{array}{c}\text { Med } \\
(\min -\max )\end{array}$ & $15(5-61)$ & $17(4-78)$ & $17(6-36)$ & 0,004 & 0,027 & 0,657 \\
\hline
\end{tabular}




\begin{tabular}{|c|c|c|c|c|c|c|c|}
\hline $\operatorname{AST}(\mathrm{IU} / \mathrm{L}) *$ & $\begin{array}{c}\text { Med } \\
(\min -\max )\end{array}$ & $18(9-50)$ & $19(11-73)$ & $18(9-26)$ & 0,250 & 0,832 & 0,403 \\
\hline D vitamini* & $\begin{array}{c}\text { Med } \\
(\min -\max )\end{array}$ & $21(4-122)$ & $18(4-105)$ & $16(5-33)$ & 0,046 & 0,002 & 0,148 \\
\hline Magnezyum* & $\begin{array}{c}\text { Med } \\
(\min -\max )\end{array}$ & $2(1,4-2,7)$ & $2(1,7-4,7)$ & $2(1,7-4,7)$ & 0,901 & 0,762 & 0,702 \\
\hline Kalsiyum* & $\begin{array}{c}\text { Med } \\
(\min -\max )\end{array}$ & $9,4(8,2-10,6)$ & $\begin{array}{c}9,4(8,5- \\
11,3)\end{array}$ & $9,3(8,6-10,7)$ & 0,886 & 0,766 & 0,682 \\
\hline Fosfor* & $\begin{array}{c}\text { Med } \\
\text { (min-max) }\end{array}$ & $3,6(2-4,7)$ & $3,5(2,3-4,6)$ & $3,5(2,5-4,5)$ & 0,075 & 0,735 & 0,291 \\
\hline Albümin* & $\begin{array}{c}\text { Med } \\
(\min -\max )\end{array}$ & $4,1(0,9-4,7)$ & $4,2(3,5-4,8)$ & $4,1(3,7-4,7)$ & 0,107 & 0,533 & 0,427 \\
\hline $\begin{array}{l}\text { C-Reaktif } \\
\text { Protein* }\end{array}$ & $\begin{array}{c}\text { Med } \\
\text { (min-max) }\end{array}$ & $2,3(0-104)$ & $3(0-23)$ & $2(0,6-26,7)$ & 0,833 & 0,636 & 0,579 \\
\hline Sedim* & $\begin{array}{c}\text { Med } \\
\text { (min-max) }\end{array}$ & $13(2-68)$ & $13(2-40)$ & $14(3-52)$ & 0,436 & 0,881 & 0,509 \\
\hline WBC* & $\begin{array}{c}\text { Med } \\
(\min -\max )\end{array}$ & $6,2(4-12,7)$ & $\begin{array}{c}6,2(3,7- \\
13,9)\end{array}$ & $5,7(4,6-10,4)$ & 0,662 & 0,201 & 0,479 \\
\hline $\begin{array}{l}\text { Trombosit } \\
\text { Sayısı* }\end{array}$ & $\begin{array}{c}\text { Med } \\
\text { (min-max) }\end{array}$ & $\begin{array}{c}262,5(128- \\
474)\end{array}$ & $\begin{array}{c}254,5(133- \\
831)\end{array}$ & $\begin{array}{c}249,5(171- \\
418)\end{array}$ & 0,846 & 0,446 & 0,636 \\
\hline MPV* & $\begin{array}{c}\text { Med } \\
\text { (min-max) }\end{array}$ & $8,3(6,6-11,4)$ & $\begin{array}{c}8,3(6,8- \\
11,1)\end{array}$ & $8,3(6,4-10,9)$ & 0,781 & 0,634 & 0,839 \\
\hline PDW* & $\begin{array}{c}\text { Med } \\
\text { (min-max) }\end{array}$ & $15,6(2,9-19,3)$ & $\begin{array}{c}15,3(11,2- \\
16,9)\end{array}$ & $15,6(8,8-17,1)$ & 0,027 & 0,833 & 0,186 \\
\hline $\begin{array}{l}\text { MPV/Platelet } \\
*\end{array}$ & $\begin{array}{c}\text { Med } \\
\text { (min-max) }\end{array}$ & $\begin{array}{c}0,03(0,02- \\
0,07)\end{array}$ & $\begin{array}{c}0,03(0,01- \\
0,06)\end{array}$ & $\begin{array}{c}0,03(0,02- \\
0,06)\end{array}$ & 0,965 & 0,740 & 0,850 \\
\hline $\begin{array}{l}\text { Nötrofil/Lenf } \\
\text { osit* }\end{array}$ & $\begin{array}{c}\text { Med } \\
\text { (min-max) }\end{array}$ & $1,4(0,2-30)$ & $1,5(0,6-32)$ & $1,2(0,5-3,1)$ & 0,984 & 0,015 & 0,023 \\
\hline $\begin{array}{l}\text { KMD Skoru } \\
\text { (Femur total) }\end{array}$ & $\begin{array}{c}\text { Med } \\
\text { (min-max) }\end{array}$ & $-2,2(-5,2-0,5)$ & $\begin{array}{l}-1,5((-2,4)- \\
1,8)\end{array}$ & $0,3((-0,8)-3,4)$ & & & \\
\hline $\begin{array}{l}\text { KMD Skoru } \\
\text { (Lomber) }\end{array}$ & $\begin{array}{c}\text { Med } \\
(\min -\max )\end{array}$ & $\begin{array}{l}-2,5((-2,8)- \\
1,6)\end{array}$ & $\begin{array}{l}-1,5((-2,4)- \\
1,4)\end{array}$ & $0,9((-0,9)-7,3)$ & & & \\
\hline
\end{tabular}

*Mann Whitney U testi; **Ki-kare testi. A: Osteoporoz grubu ile osteopeni grubu; B: Osteoporoz grubu ile kontrol grubu; C: Osteopeni ile kontrol grubu. ALT: Alanin Aminotransferaz; AST: Aspartat Aminotransferaz; WBC: White Blood Cell; MPV: Mean Platelet Volume; PDW; Platelet Distribution Width. KMD: Kemik Mineral Dansitometri

Tablo 2. KMD skorları ile laboratuar parametreleri arasındaki ilişki

\begin{tabular}{|c|c|c|c|}
\hline & & KMD Skoru (Femur & KMD Skoru \\
\hline \multirow{2}{*}{ Platelet Sayısı } & Rho & $-0,048$ & 0,045 \\
\hline & $p$ & 0,430 & 0,466 \\
\hline \multirow[t]{2}{*}{ MPV/Platelet SayısI } & Rho & 0,021 & $-0,078$ \\
\hline & $p$ & 0,730 & 0,205 \\
\hline \multirow[t]{2}{*}{ Nötrofil/Lenfosit } & Rho & $-0,175$ & $-0,011$ \\
\hline & $p$ & 0,004 & 0,864 \\
\hline \multirow[t]{2}{*}{ MPV } & Rho & $-0,055$ & $-0,076$ \\
\hline & $p$ & 0,369 & 0,218 \\
\hline \multirow[t]{2}{*}{ PDW } & Rho & $-0,032$ & $-0,013$ \\
\hline & $p$ & 0,599 & 0,830 \\
\hline
\end{tabular}

MPV: Mean Platelet Volume; PDW; Platelet Distribution Width. KMD: Kemik Mineral Dansitometri. 


\section{Tartışma ve Sonuç}

Çalışmamızda osteoporozu olan hastaların hem osteopenik hem de kontrol grubu olan hastalarla karşılaştırıldığında daha yaşlı olduğu saptandı. Aspray ve ark.larının yaptığ çalışmada da yaşın osteoporoza bağl1 gelişebilecek fraktürlerde en önemli etken olduğu kanıtlanmıştır. FRAX kriterlerine (11) göre 65 yaş üstü kadınlarda ve erkeklerde ayrıca kortikosteroid kullanımı, erken yaşta menapoz başlangıcı gibi riskli gruplarda olanlara mutlaka osteoporoz için değerlendirilme yapılması gerektiği bildirilmektedir. DEXA'nın KMD'yi değerlendirmede en güvenilir yöntemlerden biri olduğunu da bildirmektedir. Aspray ve ark'ları, yaş artıkça osteoporozun da arttığını bu nedenle de yaşlilarda osteoporozun daha fazla dikkate araştırılması gerektiğini savunmaktadırlar (12). Bizim yaptığımız çalışmada da osteoporoz grubu daha yaşlıydı.

Lane ve ark'larının yaptığı çalışmada osteoporozun dünyada yaşlı nüfusun artmasıyla bir halk sağlı̆̆ problemi haline geldiği savunmaktadır. Özellikle 65 yaşın üzerindeki tüm kadınların, 65 yaş altı risk faktörleri olan postmenopozal kadınların ve kırık geçmişi olan menopoz sonrası kadınların mutlaka osteoporoz açısından sıkı takip edilmesi gerektiğini de savunmaktadır (13). Bizim çalışmamızda da literatüre benzer şekilde yaş ve kadın cinsiyet osteoporoz ile anlamlı olarak ilişkili saptanmıştır.

Garnero ve ark'larının postmenopozal kadınlar üzerinde yaptığı çalışmada, postmenopozal yaşlı kadınlarda kemik oluşumu ve resorpsiyonunun yüksek olduğunu saptamıştır. Garnero ve ark'ları yaşlılıklarda özellikle D vitamini eksikliğinin de etkisiyle sekonder hiperparatiroidizm gelişebileceğini bunun da kemik rezorbsiyonu etkileyebleceğini savunmaktadır (14). Özellikle menopoz sonrası overlerin fonksiyonunu kaybetmesine bağlı olarak kadınlarda osteoporoz riski artmaktadır ve kadın cinsiyet osteoporoza daha duyarlı hale gelmektedir. Çalışmamızda kemik kitlesinin azalmasını düşündüren şikayetlerle kadınların, erkeklerden daha fazla poliklinik başvurusunda bulunduğu saptand $1(p<0,05)$.
Akbal ve ark'ları yapmış oldukları çalışmada, trombosit fonksiyonlariyla kemik mineralizasyonu arasında bir ilişkili olduğu göstermişlerdir. Trombosit fonksiyonlarının belirteçleri olan PDW ile osteoporoz arasında da anlamlı bir ilişki saptanmıştır ancak MPV değerlerinde azalma ile anlamlı bir ilişki saptanmamıştır. Akbal ve arkadaşları klinik uygulamalarda basit yöntemlerden biri olan MPV ve PDW değerlerindeki azalma ile lomber ve femur $\mathrm{T}$ değerleri arasında ilişki olduğunu ayrıca trombosit fonksiyonlarındaki azalmanın, kemik oluşumunda bozulmaya yol açtığı hipotezini savunmaktadırlar (15). Ayrıca Li ve ark'larının yaptı̆̆ 1 başka bir çalışmada da MPV ile osteoporoz arasında bir ilişki olabileceğini, ama yapılan çalışmalar bu ilişkinin ortaya konulmasında yetersiz kaldığını savunmuşlar MPV değerleri ile KMD arasındaki negatif ilişkinin kemik kaybı ile damar hastalığı arasında bir ilişkiden kaynaklanabileceği fikrine bağlamışlardır. Ancak trombosit sayıları ile KMD arasında anlamlı bir ilişki olmadığını bulmuşlardır (16). Bizim çalışmamızda MPV değerleri incelendiğinde, kemik kitlesinin azaldı̆̆ durumlar ile (ostoporoz ve osteopeni) kontrol grubu arasında anlamlı bir ilişki yoktu $(p>0,05)$. PDW değerleri incelendiğinde ise osteoporozu olan hastalar ile osteopenik hastalar arasında, istatiksel olarak anlamlı bir fark olduğu saptand $1 \quad(p=0,0027)$. Ayrıca yaptığımız çalışmada da platelet sayısı ile KMD arasında anlamlı bir ilişki saptanmadı $(p>0,05)$. Kandaki MPV ve PDW gibi değerlerin, kan örneğinin alınma tekniğinden, saklanmasına ve çalışılma tekniğine kadar birçok faktörden etkilendiği de bilinmektedir. Aypak ve ark'larının obezitesi olan osteoporotik hastalarda yapmış oldukları çalışmada, özellikle Femur boynu kemik mineral yoğunluğu ile MPV arasında ters bir ilişki olduğunu saptamışlardır. Bu nedenle de aşırı kilolu veya obez kişilerde MPV değerlerinde azalmanın osteoporoz ile ilişkili olabileceğini savunmuşlardır (17). Oysa Toplak ve ark'ları ise yaptıkları çalışmada kilo vermenin ve düşük kalorili diyetin MPV değerlerinde düşme meydana getirdiğini bildirmektedir. Hatta aterosklerotik kalp hastalığ1 ve serebrovasküler beyin hastalığ 
bulunanlarda diyetle, MPV değerlerinin düşürülerek bu tromboembolik olaylardan korunulabileceğini savunmaktadırlar (18). Noris ve ark'ları yaptıkları bir çalışma ise trombositlerin çok kolay etkilenebileceğini ve MPV değerlerinin standardizasyon güçlüklerinden bahsetmiş ve MPV değerlerinin hastalıklar için o kadarda önemli olmadığını söylemektedir (19). Hatta MPV değerlerinin yeni sentezlenen trombositler nedeniyle yüksek olabileceği bildirilmektedir. Nitekim Eroğlu ve ark'larının yaptığ çalışmada MPV değeri ile KMD değerleri arasında istatiksel ilişki bulamamıştır $(p=0,74)$ ancak $\mathrm{D}$ vitamini düşüklüğü ile osteoporoz arasında kuvvetli bir ilişki olduğu saptanmıştır (20).

Cranney ve ark'ları osteoporoz üzerine yapılmış 167 adet çalışmayı karşılaştırmıştır. Dolaşımdaki D vitamini miktarının, kemik sağlığına olumlu etkilerinin olduğunu ama net olarak bu D vitamini eşik değerinin bilinemediğini vurgulamaktadır. Ama çoğu çalışmada günlük 700 İU/gün D vitamini ve birlikte $\mathrm{Ca}$ verilmesinin osteoporozu ve fraktür riskini küçük miktarda da olsa azalttığ1 saptamışlardır (21). Çalışmamızda özellikle osteoporozu olan hastalarda D vitamini düzeylerinin yüksek olduğu saptandı. Bu durumu, osteoporozu olan hastalarm, dışarıdan $D$ vitamini veya $D$ vitamini içeren takviye edici gıdalar almış olabileceği, şeklinde yorumladık. Trautvetter ve ark'larının yaptığı başka bir çalışmada ise, $\mathrm{Ca}$ ve $\mathrm{D}$ vitamininin birlikte verilmesi, kemiklerin yapısının korunmasında faydalı olduğunu saptamışlardır. Yine aynı çalışmada $\mathrm{Ca}, \mathrm{P}$ ve $\mathrm{D}$ vitamininin birlikte verilmesinin sadece vücuttan atılan $\mathrm{Ca}$ ve P'u arttırırken kemik yapısının korunmasına fayda etmediğini de savunmuşlardır (22). Bizim çalışmamızda kemik kitlesinin D vitamini ile negatif yönde anlamlı ilişkisinin $(\mathrm{p}<0,01)$ olduğunu saptarken, $\mathrm{Ca}$ ve $\mathrm{P}$ ile ilişkisinin olmadığ $\quad(p>0,05) \quad$ saptand. Meier ve ark'larının yaptığı çalışmada ise özellikle kış aylarında D vitamini ihtiyacının arttığını belirtmiştir. Çalışmasının devamında da denek grupları arasında ağızdan D3 vitamini ve Ca takviyesi alan grubun, diğer gruplara oranla kemik kitlesinin korunduğunu ve kemik kaybının önlendiğini saptamıştır. Meier ve ark'ları bu sonuçlardan yola çıkarak özellikle kış aylarında gözlenen D vitamini eksikliğinin ve sekonder gelişebilecek hafif hiperparatiroidizmin zamanla ostepeni ve osteoporozun patogenezinde rol aldığını ve bunun önlenmesinde, kışın takviye olarak alınacak $\mathrm{D}$ vitamini ve $\mathrm{Ca}$ olabileceğini savunmaktadır (23). D vitamininin, kemik kitlesinin korunmasında rol oynadığı gösterilmiştir.

Karakaş ve ark'ları. 70 adet 65 yaş üstü hasta üzerinde yaptıkları çalışmada kan CRP düzeylerinin ölçülmesi osteoporotik geriatrik hastalarda tarama metodolojisi olarak kullanılabileceğini savunmuşlardır (24). Yapmış olduğumuz bu çalışmada CRP değerinin ne osteoporozu olan ne de osteopenisi olan hasta grubuyla kontrol grubu arasında anlamlı bir ilişkinin olmadığı saptandı $(p>0,05)$. Çalışmamızın en büyük avantaj1 Karakaş ve ark'larının vaka sayılarından (n:35 osteoporotik- n:35 kontrol grubu) daha fazla vaka sayılarımızın (n:159 osteoporoz- n:78 osteopeni- n:45 kontrol grubu) olmasıydı ve ayrıca kemik kitlesi azalan hastaları 3 gruba ayırarak, grupları birbiri arasında değerlendirmiş olmamızdı.

Aypak ve ark'larının yaptığı başka bir çalışmada da kan biyokimya değerleri ve iyonlar $(\mathrm{Ca}, \mathrm{P}, \mathrm{Mg}, \mathrm{K})$ ile osteoporoz arasında istatiksel olarak anlamlı bir ilişki yokken MPV ile ilişkili olduğu saptamıştır. Sonrasinda da MPV ile özellikle femoral boyun KMD si arasında bir bağlantı olduğunu belirtmişlerdir (17). Bizim çalışmamız ise lomber bölgede osteoporoz daha fazlaydı. Ama kan biyokimya ve iyon değerleri (albümin, AST, Ca, Mg, P) ile osteoporoz arasında anlamlı bir ilişki bulunmadığı saptand $1 \quad(p<0,05)$. Glikoz osteopenik hastalarda $(\mathrm{p}<0,05)$, üre, ürik asit, kreatin ve ALT (negatif yönde) osteoporotik hastalarda istatiksel açıdan anlamlı farklılıklar olduğu saptand $1(p<0,05)$.

Boyraz ve ark'larının 25 kişilik bir deney grubunda yaptıkları bir çalışmada, osteoporozu olan hastalar ile kontrol grubunun NLO değerleri arasında bir ilişki olmadığı saptanmıştır (25). Ancak bizim çalışmamızda osteoporozu olan vakalarda NLO değerlerinin arttığ1 saptandı $(p<0,05)$. $\mathrm{Bu}$ artışın sebebi, osteoporozun patogenezinde 
inflamasyon varlığının olması mı yoksa osteoporoza bağlı inflamatuvar süreçlerin başlaması mı olduğunun anlaşılması, için yeni çalışmalara ihtiyaç vardır. Ayrıca bizim yaptığımız bu çalışma, Boyraz ve ark'larının yaptığ çalışmadan daha fazla sayıda hastayı içerdiği için daha anlamlı sonuçlar çıkabileceği düşünüldü.

Çalışmamızın bazı sınırlılıkları vardı. Birincisi, osteoporotik şikayetlerle polikliniğe başvuran hastalar üzerinde bu çalışmanın dizayn edilmiş olması nedeniyle, kontrol grubu hasta sayısinin az olmasiydi. Ayrica hastaların $\mathrm{D}$ vitamini içeren destek ürünleri hekim önerisi dışında kullanması sebebiyle D vitamini ve kemik mineral dansitesini içeren karşılaştırmalar yanıltıcı sonuçlara sebebiyet vermiştir. Ek olarak yapılan çalışmalarda değerlendirdiğimiz biyokimyasal parametrelerin, obezite ile de ilişkili

\section{KAYNAKLAR}

1. Armas LA, Recker RR. Pathophysiology of osteoporosis: new mechanistic insights. Endocrinol Metab Clin North Am. 2012;41:475-486.

2. Lane JM, Russell L, Khan SN. Osteoporosis. Clin Orthop Relat Res. 2000;139-150.

3. Burge R, Dawson-Hughes B, Solomon DH, Wong JB, King A, Tosteson A. Incidence and economic burden of osteoporosis-related fractures in the United States, 2005-2025. J Bone Miner Res. 2007;22:465-475.

4. Dünya Sağl1k Örgütü (27.10.2003). Musculoskeletal conditions affect millions, Erişim tarihi: 23.03.2021, https://www.who.int/news/item/27-10-2003musculoskeletal-conditions-affect-millions,

5. Beeton CA, Bord S, Ireland D, Compston JE. Osteoclast formation and bone resorption are inhibited by megakaryocytes. Bone. 2006;39:985990.

6. Ciovacco WA, Cheng YH, Horowitz MC, Kacena MA. Immature and mature megakaryocytes enhance osteoblast proliferation and inhibit osteoclast formation. $J$ Cell Biochem. 2010;109:774-81.

7. Watts NB, Bilezikian JP, Camacho PM, Greenspan SL, Harris ST, Hodgson SF, et al. American Association of Clinical Endocrinologists Medical Guidelines for Clinical Practice for the diagnosis and treatment of postmenopausal osteoporosis. Endocr Pract. 2010;16 Suppl 3:1-37.

8. Holick MF. Vitamin D and bone health. $J$ Nutr. 1996;126:1159S-64S. bulunması sebebiyle kilo değerlendirmesinin de katılacağı prospektif kontrollü çalışmalara ihtiyaç vardır.

Çalışmamız sonucunda osteoporoz ile PDW ve NLO oranı arasında anlamlı bir ilişki saptand1. Osteoporoz zemininde herhangi bir inflamasyon mevcudiyeti ya da osteoporozun kendisinin başlattığı bir inflamasyon sebebiyle bu ilişki saptanmış olabilir. Ancak hemogram gibi basit ve her kurumda kolaylıkla yapılabilecek bir kan tetkikinde bu artışın yaş faktörü de göz önüne alınarak osteoporoz yönünden uyarıcı olabileceğini düşünmekteyiz.

\section{Teşekkür}

Bu çalışmamızda desteklerini bizden esirgemeyen Yoncall Fizik Tedavi ve Rehabilitasyon Hastanesi yönetimine, Fizik Tedavi Uzmanı Dr. İbrahim Özdemir ve Saniye Bayır'a teşekkür ederiz.

9. Cosman F, de Beur SJ, LeBoff MS, Lewiecki EM, Tanner B, Randall S, et al. Clinician's Guide to Prevention and Treatment of Osteoporosis [published correction appears in Osteoporos Int 2015;26:2045-7]. Osteoporos Int. 2014;25:235981.

10. Akpolat V, Osteoporoz Tanısında Kullanılan Kemik Mineral Yoğunluğu Ölçüm Yöntemleri, Dicle Tip Dergisi,2008;35: 216 - 20

11. Hernlund E, Svedbom A, Ivergård M, Compston J, Cooper C, Stenmark J, et al. Osteoporosis in the European Union: medical management, epidemiology and economic burden. A report prepared in collaboration with the International Osteoporosis Foundation (IOF) and the European Federation of Pharmaceutical Industry Associations (EFPIA). Arch Osteoporos. 2013;8:136.

12. Aspray TJ, Hill TR. Osteoporosis and the Ageing Skeleton. Subcell Biochem. 2019;91:453-76.

13. Lane NE. Epidemiology, etiology, and diagnosis of osteoporosis. Am J Obstet Gynecol. 2006; 194:S3-S11.

14. Garnero P, Sornay-Rendu E, Chapuy MC, Delmas PD. Increased bone turnover in late postmenopausal women is a major determinant of osteoporosis. J Bone Miner Res. 1996;11):337-49.

15. Akbal A, Gökmen $F$, Gencer $M$, Inceer BS, Kömürcü E. Mean platelet volume and platelet distribution width can be related to bone mineralization. Osteoporos Int. 2014,25):2291-95.

16. Li XS, Zhang JR, Meng SY, Li Y, Wang RT. Mean platelet volume is negatively associated with bone mineral density in postmenopausal women. J Bone Miner Metab. 2012;30:660-65. 
17. Aypak C, Türedi Ö, Bircan MA, Civelek GM, Araz M. Association between mean platelet volume and bone mineral density in postmenopausal women. $J$ Phys Ther Sci. 2016;28:1753-58.

18. Toplak H, Wascher TC. Influence of weight reduction on platelet volume: different effects of a hypocaloric diet and a very low calorie diet. Eur $J$ Clin Invest. 1994;24:778-80.

19. Noris P, Melazzini F, Balduini CL. New roles for mean platelet volume measurement in the clinical practice?. Platelets. 2016;27:607-12.

20. Eroglu S, Karatas G. Platelet/lymphocyte ratio is an independent predictor for osteoporosis. Saudi Med J. 2019;40:360-66.

21. Cranney A, Horsley T, O'Donnell S, Weiler H, Puil L, Ooi D, et al. Effectiveness and safety of vitamin D in relation to bone health. Evid Rep Technol Assess (Full Rep). 2007;1-235.

22. Trautvetter U, Neef N, Leiterer M, Kiehntopf M, Kratzsch J, Jahreis G. Effect of calcium phosphate and vitamin $\mathrm{D}_{3}$ supplementation on bone remodelling and metabolism of calcium, phosphorus, magnesium and iron. Nutr J. 2014; $13: 6$

23. Meier C, Woitge HW, Witte K, Lemmer B, Seibel MJ. Supplementation with oral vitamin D3 and calcium during winter prevents seasonal bone loss: a randomized controlled open-label prospective trial. J Bone Miner Res. 2004;19:1221-30.

24. Karakas EY, Yetisgin A, Cadirci D, Sezen H, Altunbas R, Kas F, et al. Usefulness of ceruloplasmin testing as a screening methodology for geriatric patients with osteoporosis. J Phys Ther Sci. 2016;28:235-39.

25. Boyraz İ, Çağlar H, Karakoyun A, Koç B, Gündüz R. Evaluation of Inflammation in Pathogenesis of Osteoporosis with Neutrophil Lymphocyte and Platelet-LymphocyteRatios; Türk Osteoporoz Dergisi 2015; 21:159-60 